\section{STUDENTS' VIEW TOWARD ONLINE CLASS FOR TEACHING SEMIOTICS IN COVID-19 PANDEMIC TERM}

\author{
Riski Amrina Sari \\ English Literature Study Program, Sekolah Tinggi Bahasa Asing Pontianak \\ riskiamrinasari@ymail.com
}

Online

Learning, Google

Classroom,

Video

Conference

105

\begin{abstract}
This research explains students' views toward online classes in semiotics class during the COVID-19 pandemic term. The purposes of this research are to identify students' views toward online classes and the other purpose is to know the benefit of online classes based on the students' view. This research was used descriptive qualitative research. In this research students of the sixth semester of the English Literature Study Program at STBA Pontianak to be participants. The interview was used to collect the data. The findings showed that there is a positive and negative view of the participants in online learning. Positive view from the participants by doing online class they know more about technology related to media for online study. Due to the rapid change in education so online classes help the students in mastering the skill to face the era 21 st century. Negative view, they said that online class is not effective as same as a face-to-face learning activity, even the lecturer has used video conference but the slow internet connection to be the problem for the students to understand what the lecturer explained. When the internet network was bad, the Google Classroom and video conference cannot work correctly, and the lack of internet quota will be a big problem for the participants. Besides, the finding of the benefit of the online class, the participants expressed that online learning is efficient in term of time, they just learning at home, through the online class they feel confident in giving an opinion about the material. In giving an opinion for the material the participants use their word, it can increase their vocabulary. The participants can interact more with the lecturer and peers comfortably than conventional learning.
\end{abstract}

Keywords: online learning, Google Classroom, Video conference, Benefit online learning

\title{
INTRODUCTION
}

Teaching is a process of transferring knowledge or information. The teaching and learning process can apply whenever and wherever. Nowadays, in era 21 st not only the economy, technology, culture, and society change rapidly, but also the educational system has grown tremendously. The development of the educational system force the users to able in using technology devices. Because the teaching-learning process not only occurs in the classroom but by using technological devices teaching-learning process can

SPECTRAL Jurnal Ilmiah STBA Vol.6 No.2 Juni 2020 ISSN 0216-3381 


\section{Online}

Learning,

Google

Classroom,

Video

Conference

106 be done by the teachers and the students. Cole (2000) as cited in Rossytawati (2018) stated that teaching and learning activities allow done by the students anytime. It means that by using technological devices teaching and learning process is not bound by distance, space, and time. Besides Khan (1997) aid that in delivering instruction and materials as an innovative approach to the remote audience using the web as the media called as online instruction. Nowadays, online learning is widely used in the teaching and learning process. The online class is used by all educational system because of the problem in this world COVID-19. The government gives a rule that all the activities include the educational system doing from home through online or computer devices.

The online class is not a new trend for the students. Aderson (2008) as cited in Rossytawaty (2018) said that E-learning, virtual learning, distance learning are included in other terms of online learning. Most students have known about the platform for creating and sharing materials online, such as Google Classroom. By using Google Classroom the lecturer conduct the teaching-learning process online. Lecturer share the materials from the Google Classroom and make discussion with all the students, not only materials, through Google Classroom lecturer create assignment or questions for students. Perez (2015) expressed that when creating assignments, giving announcements, and asking a question to make teachers easier through Google Classroom the users (teacher and students) are used the Gmail account. In using Google Classroom most students know properly, moreover in using video conferences. Even some students are not skilled in using Google Classroom they still can join with the class.

Related to this system, there are pros and contra from the students. Besides, there are many challenges to online learning. This statement is supported by Amadea and Dahesihsari (2015) the limited implementation of online learning to be the problems. The lack of connectivity and lack of understanding of the features become the problems. Moreover using video conference need more speed internet connection to make the feature performance to be maximum. Based on the explanation above the researcher needs to explore more about students' views or perceptions toward online learning during the COVID-19 pandemic term.

Each individual has different views or perceptions of something. The differences view, perception, or argument about something depends on how someone giving a response to the object. Related to online learning, students have a different view toward online class, 
every student has their view about online learning. According to Montague (1997) the students' feelings about something called students' perception. Students' view related to online learning is important to measure the condition of the class and to evaluate the effectiveness of teaching and learning activities.

Toward online learning students have a different view, there are kinds of view positive and negative views. It is called a positive view then they tend to view the process of the behavior positively and develop a positive attitude toward it. Beside negative views is the way to think about something or the impression you have of it negatively. Positive and negative views from the students are useful for the lecturer to know the condition of the class, the effectiveness of the method that is used is appropriate for the class or not. Also, Chen (2003) stated that to know the effectiveness of the class it needed students' perception. After knowing the view of the student, the lecturer can avoid the way to improve the effectiveness of the teaching and learning process. Based on the explanation above, the researcher avoids to research students' view toward online learning. This research is conducting because online learning is doing for all the subjects, and this system is new from the government to conduct online learning during the COVID-19 pandemic term.

\section{METHODS}

\section{Research Design}

In this research, the researcher used a qualitative research approach. Based on the Best (1981) descriptive qualitative studies are the research that describes the characteristics of the phenomena in society. In another meaning, descriptive qualitative research methods are used to analyze and describe the data. The purpose of this study for exploring students' thinking or argument about online class. In this case, the researcher explores students' views or arguments in using Google Classroom and video conferencing. The researcher describes and explains the arguments of the students toward online learning in semiotics class. The method was used by the researcher because the aim of this study to describe the data from the students'view and argument. 
Online

Learning,

Google

Classroom,

Video

Conference

\section{Site and Participants}

\section{Site}

Sugiono (2009:297) stated that in qualitative research there is population that called as "social situation" or "site", there are three elements in site which consists of place, actors, and activity. The site of this study was English Literature Study 108 Program, STBA Pontianak, especially 3 A1.2 class.

\section{Participants}

In qualitative research, sample is called particiants or informants, the participants were selected purposively according to several consideration and particular aim (Sugiono, 2009:298). The participants of this study were sixth semester students of STBA Pontianak especially 3A1.2 class.

\section{Data Collection}

Interview technique was used in this research for collecting the data. the researcher interview the particiants. The result of the interview will be trinscribed. The interview was conducted to get the students' view about online class and benefit of online class. The data from the interview was analyzed through the following steps, transcribing the data, classifying the data, verifying the data, and concluding students' view about online class.

\section{Data Analysis}

After collecting the data, the researcher will analyse the data from interview by some steps, The data from the interview was analyzed through the following steps, transcribing the data, classifying the data, verifying the data, and concluding students' view about online class.

\section{FINDINGS AND DISCUSSION}

\section{Findings}

\section{Students' view of online class (using of Google Classroom and Video Conference)}

The online class system was conducted for all subjects. For one-semester, they study through online by using Google Classroom and Video Conference. This system is 
new for the students because of the Covid-19 pandemic, so all activities doing at home include teaching and learning activities done from home by using E-learning. There were pros and contra to this system. The students who as participants expressed a positive view, but there was a negative view toward online class especially the use of Google Classroom and Video Conference. The participants got new experience in using Google Classroom and Vidoe Conference.

Researcher: Google Classroom and Video Conference were used during online class, what do you think?

Participant: Google Classroom and Video Conference, for online class these application is useful for us. Because of the online class, I feel more familiar with technology related to E-learning.

Participant: according to me online class is not effective because the process of learning changes from face-to-face to be online, all of the materials from the lecturer in file form so it needs to read the materials. Sometimes we could not understand if it is just read without explanation directly from the lecturer.

The answer of the participants shows that there is a positive and negative view related to online class especially the use of Google Classroom and Video Conference. The first participant has a positive view of an online class. It gives new information about another E-learning. Video conference is a new experience for the participant.

Besides, the second participant has a negative view, face-to-face is better than an online class. face-to-face class is more effective than an online class because they just read the material without hearing from the lecturer directly.

Researcher: do you think that using Google Classroom and Video Conference ncreases the effectiveness of learning semiotics?

Participant: this change give an effect on the understanding of each student. Teaching-learning activities are not effective because of the limitation of time and lack of connection, moreover when using video conferences. 
Online

Learning, Google

Classroom,

Video

Conference

Participant: it is not effective, I just understand a little bit about the material sometimes I do not understand all the material. When using Video conference its enough to make me understand but the slow of connection is the problem.

Participant: Using Google Classroom and Video Conference are not as effective as the face-to-face teaching-learning process. The lack of connection caused the video conference is not good in sound and picture, beside Google Classroon is not work well, so the explanation from the lecturer is not clear.

Participant: Google Classroom and Video Classroom need an online connection and it spends much money to buy quota.

The point of view of the participants showed that using Google Classroom and Video Conference is not more effective than face-to-face teaching-learning activities. Moreover, the lack of time and connection to be a problem in conducting the online class. It means that the teaching-learning process is not well due to the obstacle of the slow internet connection and the participants need more quota.

\section{Students' View of the Benefit of Online Class (Using Google Classroom and Video Conference) For Learning Semiotics}

From the data obtained from participants, they had a positive view toward the benefit of the online class using Google Classroom and video conference help some of them to be confident, motivate in learning and of course, they get new vocabulary when they give opinions through Google Classroom and video conference.

Researcher: do you think that the online class has an advantage?

Participant: for me, during online class, I can train myself to be more independent in the learning process

Participant: online class make us more responsible because online class require more motivation 
Participants' view above obtained through the interview, they were being Learning, independent and more responsible for conducting the online class. When the lecturer asks the opinion they try to find out by themselves, read and conclude what they have read, and then share the opinion at Google Classroom, it makes them more independent in Google Classroom, learning online. Their diligently and actively joining the online class will determine their score.

Participant: we can ask more to the lecturer and feel more confidence through an online class

Participant: giving comments toward the lecturer's questions easy for me now, I am not shy and afraid, I get new English vocabulary by reading the material.

It means that through online classes helps them more active in giving an opinion, they can interact with the teacher and their peers more than conventional class. Al-khatiri (2015) stated that chat in the E-learning to be a facility for shy students because the chat feature makes the students confident and motivated to interact more with the teacher and peers. Moreover, through group work that is given by the lecturer can encourage students' anxiety.

Participant: we can study from home so it is no need to go to the campus in a hurry

Participant: we obtained more understanding of using technology and increase our knowledge

The data showed that online class has efficient time for the students, they can learn from home without having to come to the campus. Online classes give chance to the students to know more about the technology related to E-learning.

From the data finding through the interview, it can be concluded that the online class system during one semester in the Covid-19 pandemic term in learning semiotics there is a positive and negative view from the participants. Some of the participants have a positive view of an online class. They said that by doing online classes they know more 


\section{Online}

Learning, Google

Classroom,

Video

Conference

112

about technology related to media for online study. Due to the rapid change in education so online classes help the students in mastering the skill to face the era 21 st century. Furthermore, an online class is efficient in terms of time, they agreed online learning can save time, they do not need to prepare to go to campus. Through online classes, they feel confident in giving an opinion about the material. On the other hand, some other participants expressed their negative views about online classes. They said that online class is not effective as same as a face-to-face learning activity, even though the lecturer has used video conference but the slow internet connection to be the problem for the students to understand what the lecturer explained. When the internet network was bad, the Google Classroom and video conference can not work correctly. They emphasized that direct explanation can help them to understand the material, if they do not understand they can ask the teacher to re-explain the material. They said face-to-face learning allows them to interact directly with their friend, so they are motivated to study. There is some benefit of online learning for the participants, the participants agree that online learning is efficient in terms of time, they just learning from home without any preparation to go to campus. Through online classes, they feel confident in giving an opinion about the material, and they obtain more vocabulary when they giving opinion In giving an opinion for the material the participants use their word, it can increase their vocabulary. The participants can interact more with the lecturer and peers comfortably than conventional learning. In this research, the researcher hopes that the result will be useful for further researchers who are interested to conduct a similar study.

\section{Discussion}

Students' views and the benefit of the online class to be the purposes of this research. In this case, the students conduct learning activities use Google Classroom and video conference. in conducting online classes using Google Classroom and video conference, the students expressed that online class is not more effective as a conventional class or face-to-face. Beside, there are benefit of online class, they more confident in giving opinion and have efficient time without going to campus. In this research, there are different findings because of their different subject. In Islam (2018) result in the result of this research obtained that Bangladeshi students using Google Classroom are not effective without any proper training before. They expressed that using both the teacher and Google Classroom will be more effective in learning English. Contrast with 
Cakrawati (2017), the result of this study the use of Edmodo and Quipper in teaching and learning English is effective and efficient in terms of time, even though the slow-speed of the internet to be a problem. In line with Anwar, et. Al. (2019) there are diverse perceptions from the sample, but most of the students have a positive attitude toward using Padlet in learning Linguistics. The students said that the display of Padlet is interesting with the features available. The use of Padlet is easier for the students and they more understand when learning by using Padlet.

Nowadays, Google Classroom and video conferences to be a tool in conducting teaching and learning process. Deu to the problem in the world COVID-19 pandemic term, the process teaching and learning process through online. All of the students use these tools to still keep study even though they are not in class. Even the skill of using these tools to be challenges for the students, moreover the lack of the internet connection to be the problem, but these problems do not seem to be serious influence their anxiety to still learning from home.

\section{CONCLUSION}

This research focused on student's views toward online class (using Google Classroom and video conference) during learning from home. The data from the participants were then analyzed to get the result. This research found that students have a positive and negative view of online classes using Google Classroom and video conference. Even most students expressed that conventional learning more effective than online but they still can following the online class enjoyably. Besides online classes contribute to the positive impact for the students who have less skill in technology and give chances for the students to more active in giving opinions in an online class than in conventional class because they shy. This research expects useful for the readers and hopes to make the reader understand and interested in doing the other research about student's perspective or perception. And the researcher would like to give suggestions for the other researchers who are interested in conducting relevant research especially for English department students and linguistic students to read this paper as additional information. Furthermore, the next researchers are suggested to use different data sources. 


\section{Online}

Learning,

\section{REFERENCES}

Google

Classroom,

Video

Conference

Al-kathiri, F. (2015). Beyond the classroom walls : Edmodo in Saudi Secondary School EFL instruction, attitudes and challenges. English Language Teaching, 8(1), 189204. https://doi.org/10.5539/elt.v8n1p189

Amadea, M., \& Dahesihsari, R. (2015). Hambatan dalam Pengadopsian E-Learning pada

114 Pengajar Perguruan Tinggi di Jabodetabek. Jurnal Kependidikan.

Anderson terry. (2008). Foundations of Educational Theory for Online Learning. The Theory and Practice of Online Learning, 15-44. https://doi.org/10.1111/j.14678535.2005.00445_1.x

Best. (1981). Research in education. New Jersey: Prentice Hall Inc.

Chen, Yining, and Leon B Hoshower. (2003). "Student Evaluation of Teaching Effectiveness: An Assessment of Student Perception and Motivation." Carfax Publishing. Vol. 28 No. 1, 2003.

Montague, Marjorie. (1997). "Student Perception, Mathematical Problem Solving, and Learning Disabilities". Pennsylvania State Univ. Vol. 8 No. 1, 1997. 46-53

Perez, P. (2015). securedgenetworks. Retrieved from securedgenetworks: https://www.securedgenetworks.com/blog/how-google-classroom-is-makinginteractive-learning-more-productive

Rossytawati, Reza. (2018). A Survey Study of Students Perception in Using Google Classroom in English Language Education Department of Islamic University of Indonesia. Yogyakarta.

Sugiono. (2009). Metode Penelitian Pendidikan. Alfabeta. Bandung. 